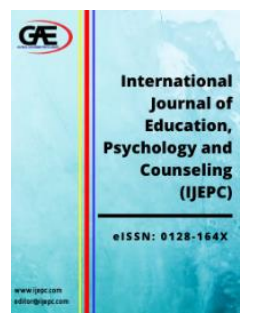

\author{
INTERNATIONAL JOURNAL OF \\ EDUCATION, PSYCHOLOGY \\ AND COUNSELLING \\ (IJEPC) \\ www.ijepc.com
}

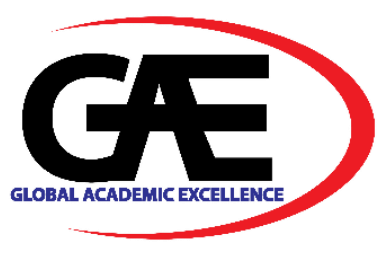

\title{
AWARENESS, KNOWLEDGE, ATTITUDE, AND PRACTICES TOWARDS SEXUAL AND REPRODUCTIVE HEALTH AMONG SECONDARY SCHOOL STUDENTS IN MALAYSIA
}

\author{
Abdul Rahman Zulkarnain ${ }^{1}$, Muhamad Nur Fariduddin²*, Ching Sin Siau ${ }^{3}$
}

1 Department of Physical \& Health Education, Faculty of Education, Universiti Teknologi MARA (UiTM), Cawangan Selangor, Kampus Puncak Alam, Selangor Darul Ehsan, Malaysia

Email: rahmanzulkarnain@gmail.com

2 Department of Physical \& Health Education, Faculty of Education, Universiti Teknologi MARA (UiTM), Cawangan Selangor, Kampus Puncak Alam, Selangor Darul Ehsan, Malaysia

Email: fariduddin@uitm.edu.my

3 Centre for Community Health Studies (ReaCH), Faculty of Health Sciences, Universiti Kebangsaan Malaysia (UKM), Jalan Raja Muda Abdul Aziz, Kuala Lumpur, Malaysia

Email: chingsin.siau@ukm.edu.my

* Corresponding Author

\section{Article Info:}

\section{Article history:}

Received date: 01.08.2021

Revised date: 01.09.2021

Accepted date: 05.09.2021

Published date: 15.09 .2021

\section{To cite this document:}

Zulkarnain, A. R., Fariduddin, M. N., \& Ching, S. S. (2021). Awareness, Knowledge, Attitude, and Practices Towards Sexual and Reproductive Health Among Secondary School Students in Malaysia. International Journal of Education, Psychology and Counselling, 6 (42), 399-412.

DOI: $10.35631 / \mathrm{IJEPC} .642031$.

\section{Abstract:}

Sexual and reproductive health matters are still taboo because it is sensitive to be discussed publicly as it opposed the norms of Malaysian people, especially among high school students. This study sought to investigate the awareness, knowledge, attitudes, and practices towards sexual and reproductive health among high school students between the ages of 13 to 17 years old in Petaling Perdana district in Selangor, Malaysia. A cross-sectional survey study was conducted among 382 secondary school students using a self-administered validated questionnaire. Descriptive and MANOVA analyses were used to analyse the data. The results showed that the level of awareness, knowledge, attitude, and practices towards sexual and reproductive health was high among all secondary school students. The MANOVA analysis yielded significant differences towards practices on gender $\mathrm{F}(1,380)=16.035, p<.001$, with males $(\mathrm{M}=1.051)$ scoring higher than females $(\mathrm{M}=.661)$, and level of education $\mathrm{F}(4,377)=7.202, p<.001$, with Form 5 students $(M=1.172)$ having the highest score. The study concluded that males had better sexual practices than females and students with a higher level of education have better understanding and practices towards their sexual and reproductive health. 


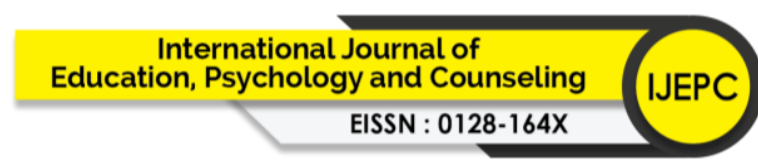

Volume 6 Issue 42 (September 2021) PP. 399-412

DOI 10.35631/IJEPC.642031

This work is licensed under CC BY 4.0

(1)
Keywords:

Attitude, Knowledge, Sexual Practice, Sexual and Reproductive Health, School Student

\section{Introduction}

According to World Health Organization (2009a), sexual health refers to a person's physical, mental, and social well-being concerning sexuality. There are many ways to deliver sexual and reproductive health information, either by learning it in their schools or receiving this knowledge from parents from the time their children experience puberty. Comprehensive sexuality education (CSE) is a curriculum-based process of teaching and learning about the cognitive, emotional, physical, and social aspects of sexuality. It aims to equip children and young people with the knowledge, skills, attitudes, and values that will empower them to optimise their health, well-being, and dignity; develop respectful social and sexual relationships; consider how their choices affect their well-being and that of others and understand and ensure the protection of their rights throughout their lives (Haberland and Rogow, 2015). The United Nations Educational, Scientific and Cultural Organization's (UNESCO) International Technical Guidance on Sexuality Education emphasizes the need for CSE programs that are scientifically accurate, incremental with a spiral-curriculum approach, age-appropriate, and most importantly culturally and context-relevant (UNESCO, 2018).

Sexuality education began to receive attention from the Malaysian government in the late 1990s. Shukor and Supaat (2018) noted that sexuality education was once integrated with the school syllabus by the Ministry of Education (MOE) since 1989 for secondary schools and then extended to primary schools in 1994. Instead of a specific subject named sexuality education, MOE integrated this program into a variety of subjects such as science, biology, religious and moral studies as well as health and physical education (Mokhtar et al, 2013). When Sexuality Education was introduced from 2003 to 2005, it was found that the term "sexuality" had a negative public perception. Hence, the term Pendidikan Kesihatan Reproduktif dan Sosial (PEERS) has been used since 20 December 2006 and was placed under Physical Fitness and Health Education. Since 2011, it has been taught as an independent (Razali et al, 2017). Handin-hand with the Ministry of Education, the Ministry of Women, Family, and Community Development launched the ACE (Accurate, Comprehensive, Effective) Sex Education module in 2016 to complement the National Policy in Reproductive Health and Social Education (LPPKN, 2010).

Among the objectives of having sexuality education in the mainstream educational system are to increase knowledge on sexual reproductive health as well as to curb potential societal issues arising from failing to practice safe sexuality, such as baby dumping, sex outside of marriage, unwanted pregnancies, unsafe abortion, and sexual abuse. However, the statistics show an increasing number of sexual reproductive issues among adolescents. The latest Malaysian Population and Family Survey (MPFS) in 2014 (LPPKN, 2010) indicated that Malaysian adolescents have inadequate knowledge of their reproductive organs, where $55 \%$ of them are aware of the transmission of HIV/AIDS through sexual actions, and 73\% know about sexually transmitted diseases (STDs) through sexual intercourse. In addition, the number of unwanted pregnancies keep increasing with an estimation of around 18,000 under-aged girls falling pregnant every year in Malaysia (LPPKN, 2010). A survey conducted by the Ministry of Health Copyright (C) GLOBAL ACADEMIC EXCELLENCE (M) SDN BHD - All rights reserved 


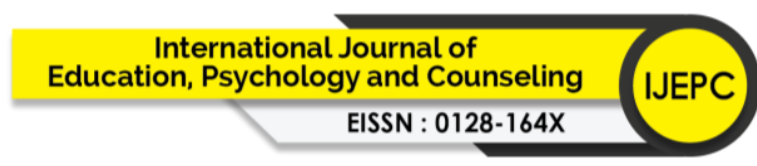

Volume 6 Issue 42 (September 2021) PP. 399-412

DOI 10.35631/IJEPC.642031

$(\mathrm{MOH})$ in 2015 found that most female youth lacked sexual reproductive health knowledge and worse, claimed to have learned about the term "sexual" from online sources instead of the school curriculum.

The importance of the student's knowledge, attitude, and awareness towards their sexual reproductive health is very crucial because most of the time, most of them are unmarried and their involvement in premarital sexual intercourse may lead towards unwanted pregnancies and sexually transmitted diseases due to the lack of knowledge on how safe sex and contraception. A study of the "Global School-based Student Health Survey" was conducted by the Ministry of Health in 2012 to identify whether Malaysian adolescents were having sexual intercourse at this age. The results of the survey showed that of the adolescents who already had sexual intercourse, 50.4\% of the participants had sexual intercourse for the first time before the age of 14 whereas another result showed only $32.2 \%$ used a condom when they had sex last time. In 2017, the National Health and Morbidity Survey (Institute for Public Health, 2017) on adolescent health found that $7.3 \%$ of adolescents aged 13 to 17 years old had experienced sexual intercourse. Compared to the 2012 survey, the percentage of adolescents who had used a condom in their last intercourse had dropped to 12.7\% (Institute for Public Health, 2017).

Research on sexual reproductive health in Malaysia showed that adolescents continued to have poor knowledge regarding sexual reproductive health, with $75 \%$ reporting that they are uncomfortable to seek healthcare services for sexual reproductive matters such as dysmenorrhea (Othman et al, 2019). Another study among East Malaysian adolescents showed that knowledge regarding abortion laws, that individuals with STD could still look healthy, and pregnancy risk through unprotected sex was poor (Awang et al, 2014). A study among secondary school students in Kuantan, Pahang determined that upper secondary school students and smokers had better knowledge of sexual reproductive health, and only $58.4 \%$ had good knowledge of this topic (Ismail and Minhat, 2019). Among teachers, studies have shown that the implementation of sexual reproductive health education has been hampered by a lack of training among teachers and inadequate teaching and learning resources (Eshak and Zain, 2019).

Due to the culturally taboo topic, information on sexuality education is scarce particularly in the local context among high school students. The current study was designed to fill the gap in the literature to gain the level of awareness, knowledge, attitude, and practices towards sexual and reproductive health, and to further investigate the differences between gender, race, and level of education among Malaysian secondary school students.

\section{Literature Review}

\section{History of Sexual Reproductive Education in Malaysia}

Sexuality education began to receive attention from the Malaysian government in the late 1990s. Shukor and Supaat (2018) noted that sexuality education was once integrated with the school syllabus by the Ministry of Education (MOE) since 1989 for secondary schools and then extended to primary schools in 1994. Instead of a specific subject named sexuality education, MOE integrated this program into a variety of subjects such as science, biology, religious and moral studies as well as health and physical education (Mokhtar et al, 2013). When Sexuality Education was introduced from 2003 to 2005, it was found that the term "sexuality" had a negative public perception. Hence, the term Pendidikan Kesihatan Reproduktif dan Sosial 


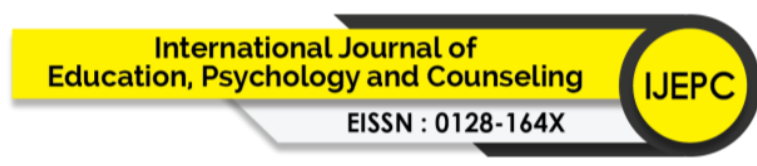

Volume 6 Issue 42 (September 2021) PP. 399-412

DOI 10.35631/IJEPC.642031

(PEERS) has been used since 20 December 2006 and was placed under Physical Fitness and Health Education. Since 2011, it has been taught as an independent (Razali et al, 2017). Handin-hand with the Ministry of Education, the Ministry of Women, Family, and Community Development launched the ACE (Accurate, Comprehensive, Effective) Sex Education module in 2016 to complement the National Policy in Reproductive Health and Social Education (LPPKN, 2017).

\section{Objectives of Sexual Reproductive Education}

Among the objectives of having sexuality education in the mainstream educational system are to increase knowledge on sexual reproductive health as well as to curb potential societal issues arising from failing to practice safe sexuality, such as baby dumping, sex outside of marriage, unwanted pregnancies, unsafe abortion, and sexual abuse. However, the statistics show an increasing number of sexual reproductive issues among adolescents. The latest Malaysian Population and Family Survey (MPFS) in 2014 (LPPKN, 2017) indicated that Malaysian adolescents have inadequate knowledge of their reproductive organs, where $55 \%$ of them are aware of the transmission of HIV/AIDS through sexual actions, and 73\% know about sexually transmitted diseases (STDs) through sexual intercourse. In addition, the number of unwanted pregnancies keep increasing with an estimation of around 18,000 under-aged girls falling pregnant every year in Malaysia (LPPKN, 2017). A survey conducted by the Ministry of Health $(\mathrm{MOH})$ in 2015 found that most female youth lacked sexual reproductive health knowledge and worse, claimed to have learned about the term "sexual" from online sources instead of the school curriculum.

\section{Importance of Student's Knowledge, Attitude, and Awareness}

The importance of the student's knowledge, attitude, and awareness towards their sexual reproductive health is very crucial because most of the time, most of them are unmarried and their involvement in premarital sexual intercourse may lead towards unwanted pregnancies and sexually transmitted diseases due to the lack of knowledge on how safe sex and contraception. A study of the "Global School-based Student Health Survey" was conducted by the Ministry of Health in 2012 to identify whether Malaysian adolescents were having sexual intercourse at this age. The results of the survey showed that of the adolescents who already had sexual intercourse, $50.4 \%$ of the participants had sexual intercourse for the first time before the age of 14 whereas another result showed only $32.2 \%$ used a condom when they had sex last time. In 2017, the National Health and Morbidity Survey (Institute for Public Health, 2017a) on adolescent health found that $7.3 \%$ of adolescents aged 13 to 17 years old had experienced sexual intercourse. Compared to the 2012 survey, the percentage of adolescents who had used a condom in their last intercourse had dropped to $12.7 \%$ (Institute for Public Health, 2017b).

\section{Methodology}

\section{Research Design}

A cross-sectional survey study was conducted in the Selangor state involving Petaling Perdana districts between September 2020 to February 2021 with a total population of 68,220 secondary school students (Ministry of Education Malaysia, 2020).

\section{Sampling and Participants}

Stratified random sampling took place, and a sample size of 382 was calculated with a $5 \%$ attrition effect from 10 different schools was selected as respondents, each with $(\mathrm{n}=38)$ 


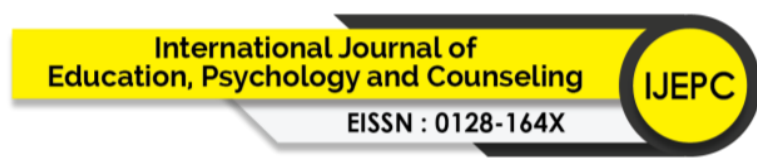

Volume 6 Issue 42 (September 2021) PP. 399-412

DOI 10.35631/IJEPC.642031

randomly representing Petaling Perdana district in Selangor state, Malaysia based on Krejcie and Morgan Sampling Method (1970). The criteria for inclusion were Malaysian high school students under MOE, and ages ranging from 13 to 17 years old.

\section{Instruments}

The employed instruments were a questionnaire derived from two studies which are "A Study on Risk and Protective Factors Affecting Adolescents' Sexual and Reproductive Health in Peninsular Malaysia by National Population and Family Planning Board" (Hassan and Sapri, 2013), and "A Study on Risk and Protective Factors Affecting Adolescents' Sexual and Reproductive Health in Sabah and Sarawak" (Hassan, 2016). The questionnaire consists of four sections, starting with demographics followed by awareness ( 7 items), knowledge (15 items), attitude (5 items), and lastly practices (4 items) on sexual and reproductive health. The face and content validity of the questionnaire had been assessed with a panel of three experts. (MM, $\mathrm{SM}, \mathrm{MH}$ ) associated with the content and language. The value of validity index (S-CVI) obtained for all items in the questionnaire is 1.00 (greater than 0.78 ) which is acceptable.

\section{Data Collection Procedure}

The awareness, knowledge, attitude, and practices on sexual and reproductive health were assessed using an online platform via a google form. A short URL link was copied and sent to the respective schools. With the head teachers' assistance, the questionnaire was distributed through an invitation sent to all students' mobile phones. All students were given two weeks to complete the questionnaire. The respective headteachers of each selected class from the schools were reminded twice to ensure all students completed the questionnaire within the time frame given.

\section{Ethical Considerations}

Due to the sensitive nature of this topic and the need for sharing personal beliefs and values, approval from the university's scientific and ethical review committee was obtained before the research was conducted. Informed consent was obtained from every respondent. The researcher did not know any of the secondary school students. Confidentiality was maintained at all stages of the study. The Faculty Ethical Committee reviewed and approved this study following the Helsinki procedures with ethical number 500-FP (PT .23/4).

\section{Data Analysis}

Data were analyzed using IBM SPSS version 27. Descriptive statistics were reported which included frequencies, mean and standard deviation describing participants' demographic characteristics, and responses on awareness, knowledge, attitude, and practices on sexual and reproductive health. A Multiple Analysis of Variance (MANOVA) test was calculated to determine the differences in gender, race, and level of education among secondary school students' level of awareness, knowledge, attitude, and practices on sexual and reproductive health. The alpha level for statistical significance was set at $\mathrm{p} \leq .05$.

\section{Results}

A total of 382 questionnaires were distributed, with a total return of 382 giving a response rate of $100 \%$. Based on Table 1 , most respondents were female $(\mathrm{n}=224 ; 58.6 \%)$, with $158(41.4 \%)$ males. The majority of the respondents were 323 (84.6\%) from Malay, $31(8.1 \%)$ from Indian, $27(7.1 \%)$ from Chinese, and $1(0.3 \%)$ from other ethnicities. There were five level of 


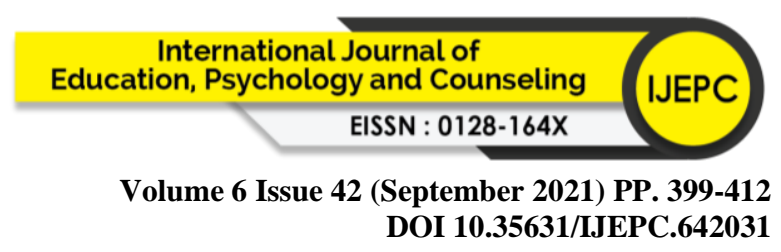

education, with $142(37.2 \%)$ form 4, 99 (25.9\%) form 5, 91 (23.8\%) form 3, 30 (7.9\%) form 2 and $20(5.2 \%)$ form 1 students, respective.

Table 1: Characteristics Of Respondents

\begin{tabular}{ccc}
\hline Demographics & No of Sample (n) & Percentage \\
\hline Gender & Male & 158 \\
& Female & 224 \\
& Malay & 323 \\
& Chinese & 27 \\
& Indian & 31 \\
Level of Education & Others & 1 \\
& Form 1 & 20 \\
& Form 2 & 30 \\
& Form 3 & 91 \\
& Form 4 & 142 \\
& Form 5 & 99 \\
\hline
\end{tabular}

Based on Table 2, 300 (78.5\%) students were aware of the period cycle. Merely half of the students were aware of the concept of HIV and AIDS diseases (58.6\%), the function and usage of a condom (58.6\%), the concept of a wet dream (56.3\%), the similarities and differences between birth control (56\%) and contraceptive pills (57.6\%), respectively. However, 214 $(56 \%)$ students were not aware of the concept of abortion services, especially in Malaysia country. The third part of the questionnaire examined the level of sexual and reproductive health knowledge among all students. Merely all students were able to answer questions one to twelve correctly.

This shows that the students had an excellent understanding of the concept of pregnancy (>84\%), including healthy sexual practice (>90\%), the concept of contraceptives (84\%), legal implications on abortion (89\%), and sexual practice on an underage girl in Malaysia (93.7\%). Nevertheless, the students failed to answer correctly on the last three items. Insufficient knowledge on the concept of STDs and the menstrual cycle could be a valid reason for the incorrect answers. The final part of the questionnaire examined the practices on sexual and reproductive health. More than half of the students have not watched $(58.4 \%)$ and read $(64.1 \%)$ materials associated with pornographic. However, $16(4.2 \%)$ of the students have experienced sexual intercourse, and $2(.5 \%)$ of students were pregnant before.

Table 2: Awareness, Knowledge \& Practices Scores On Sexual And Reproductive Health

\begin{tabular}{lcccc}
\hline & Items & $\mathbf{N}$ & $\begin{array}{c}\text { Yes } \\
\mathbf{N}(\%)\end{array}$ & $\begin{array}{c}\text { No } \\
\mathbf{N}(\%)\end{array}$ \\
\hline 1) & Awareness & & & \\
$2)$ & Period Cycle & 382 & $300(78.5 \%)$ & $82(21.5 \%)$ \\
$3)$ & HIV \& AIDS diseases & & $224(58.6 \%)$ & $158(41.4 \%)$ \\
$4)$ & Condom & $224(58.6 \%)$ & $158(41.4 \%)$ \\
$5)$ & Wet Dream & $215(56.3 \%)$ & $167(43.7 \%)$ \\
\hline & Birth Control Pills & $214(56.0 \%)$ & $168(44.0 \%)$
\end{tabular}


international Journal of

Volume 6 Issue 42 (September 2021) PP. 399-412

DOI 10.35631/IJEPC.642031

6)

Abortion Services

7)

Contraceptive Pills

\section{Knowledge}

1) Pregnancy can be prevented by using condoms.

Pregnancy can be avoided by using birth control pills.

3)

Pregnancy can be prevented by not having sexual intercourse.

4)

A woman will not get pregnant if she had sex once.

5)

Multiple partners lead to sexually transmitted diseases (STDs).

6) Abortion without any relevant reason unless causing self-harm is illegal in Malaysia.

7)

8)

9)

10)

12) A woman can get pregnant by kissing a man.

13) A woman cannot get pregnant if she had sex two weeks before her period cycle.

14) People with sexually transmitted diseases may look like normal healthy people.

Sex between men and women who have never

15) been to menstruation cannot lead to pregnancy.

\section{Practices}

1) I have watch pornographic videos.

2) I have read pornographic materials.

3) I have experienced sexual intercourse before. $\begin{array}{ll}168(44.0 \%) & 214(56.0 \%) \\ 220(57.6 \%) & 162(42.4 \%)\end{array}$

$382 \quad 353(92.4 \%) \quad 29(7.6 \%)$

$232(84.6 \%) \quad 59(15.4 \%)$

$362(94.8 \%) \quad 20(5.2 \%)$

$37(9.7 \%) \quad 345(90.3 \%)$

$353(92.4 \%) \quad 29(7.6 \%)$

$340(89.0 \%) \quad 42(11.0 \%)$

$367(96.1 \%) \quad 15(3.9 \%)$

$311(81.4 \%) \quad 31(18.6 \%)$

$360(94.2 \%) \quad 22(5.8 \%)$

$351(91.9 \%) \quad 31(8.1 \%)$

$358(93.7 \%) \quad 24(6.3 \%)$

$19(5.0 \%) \quad 363(95.0 \%)$

$79(20.7 \%) \quad 303(79.3 \%)$

$187(49.0 \%) \quad 195(51.0 \%)$

$242(63.4 \%) \quad 140(36.6 \%)$

$382 \quad 159(41.6 \%) \quad 223(58.4 \%)$

$137(35.9 \%) \quad 245(64.1 \%)$

$16(4.2 \%) \quad 366(95.8 \%)$

$2(.5 \%) \quad 380(99.5 \%)$

Based on the table 3, this is the fourth part of the questionnaire which examined the attitudes of students towards sexual and reproductive health. The majority agreed that women should avoid sexual intercourse before marriage as this action is deemed to be a serious social problem $(89 \%)$ and could possibly reduce their level of confidence and dignity (83.2\%) as a woman. Interestingly, this statement contradicts for men as half of the students (47.6\%) were unsure or 


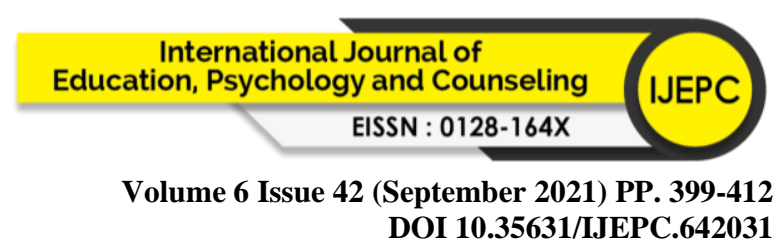

disagree if sexual intercourse before marriage should be considered as a social problem and subsequently reduces their confidence. Nevertheless, the majority disagree $(60.2 \%)$ that hugs, and kisses are permissible despite no sexual intercourse to involve. Lastly, a majority agreed $(66 \%)$ that abortion is a serious act of misconduct and should be avoided despite getting pregnant before marriage.

Table 3: Attitude Scores On Sexual And Reproductive Health

\begin{tabular}{|c|c|c|c|c|c|}
\hline Items & $\begin{array}{c}\text { Strongly } \\
\text { Disagree \& } \\
\text { Agree }(\%)\end{array}$ & Unsure (\%) & $\begin{array}{c}\text { Agree \& } \\
\text { Strongly } \\
\text { Agree (\%) }\end{array}$ & Mean & $\begin{array}{c}\text { Std. } \\
\text { Deviation }\end{array}$ \\
\hline $\begin{array}{l}\text { Sexual intercourse before } \\
\text { marriage is a serious social } \\
\text { problem. }\end{array}$ & $19(5.0 \%)$ & $23(6.0 \%)$ & $340(89.0 \%)$ & 4.63 & .866 \\
\hline $\begin{array}{l}\text { A woman will lose her } \\
\text { confidence and dignity if she } \\
\text { had sex before marriage. }\end{array}$ & $25(6.5 \%)$ & $39(10.2 \%)$ & $318(83.2 \%)$ & 4.42 & 1.016 \\
\hline $\begin{array}{l}\text { confidence and dignity if he } \\
\text { had sex before marriage. }\end{array}$ & $80(20.9 \%)$ & $102(26.7 \%)$ & $200(52.4 \%)$ & 3.61 & 1.341 \\
\hline $\begin{array}{l}\text { Hugs and kisses can be } \\
\text { considered if sexual } \\
\text { intercourse is avoidable. }\end{array}$ & $230(60.2 \%)$ & $58(15.2 \%)$ & $94(24.6 \%)$ & 2.34 & 1.472 \\
\hline $\begin{array}{c}\text { Abortion can be done if } \\
\text { partners had sex before } \\
\text { marriage. }\end{array}$ & $252(66.0 \%)$ & $78(20.4 \%)$ & $52(13.6 \%)$ & 2.04 & 1.325 \\
\hline
\end{tabular}

A multivariate analysis of variance (MANOVA) was used to examine the differences in awareness, knowledge, attitude, and practices on sexual and reproductive health among the Malaysian secondary schools' students' age, gender, and level of education. Before conducting the MANOVA, the data were examined using IBM SPSS version 27 to ensure all its underlying assumptions were met. Univariate normality was assessed with Shapiro-Wilk tests and boxplots and could be assumed. Additionally, no multivariate outliers were found in the data, supporting the assumption of multivariate normality. Correlation between the dependent variables was not excessive, indicating that multicollinearity was not of concern. Furthermore, the relationship that did exist between the dependent variables was roughly linear. Finally, Box's $\mathrm{M}$ was non-significant at $\alpha=.001$, indicating that homogeneity of variance-covariance matrices could be assumed.

Table 4: Multivariate Tests Of Awareness, Knowledge, Attitude, And Practices Towards Gender, And Level Of Education

\begin{tabular}{cccccccc}
\hline Variable & & Value & F & $\begin{array}{c}\text { Hypothesis } \\
\text { df }\end{array}$ & Error df & Sig. & $\begin{array}{c}\text { Partial Eta } \\
\text { Squared }\end{array}$ \\
\hline Gender & Pillai's Trace & .062 & $6.209 \mathrm{~b}$ & 4.000 & 377.000 & $<.001$ & .062 \\
& Wilks' Lambda & .938 & $6.209 \mathrm{~b}$ & 4.000 & 377.000 & $<.001$ & .062 \\
& $\begin{array}{c}\text { Hotelling's } \\
\text { Trace }\end{array}$ & .066 & $6.209 \mathrm{~b}$ & 4.000 & 377.000 & $<.001$ & .062
\end{tabular}




\begin{tabular}{|c|c|c|c|c|c|c|c|}
\hline \multirow{5}{*}{$\begin{array}{l}\text { Level of } \\
\text { Education }\end{array}$} & $\begin{array}{l}\text { Roy's Largest } \\
\text { Root }\end{array}$ & .066 & $6.209 b$ & 4.000 & 377.000 & $<.001$ & .062 \\
\hline & Pillai's Trace & .101 & 2.430 & 16.000 & 1508.000 & .001 & .025 \\
\hline & Wilks' Lambda & .901 & 2.471 & 16.000 & 1143.226 & .001 & .026 \\
\hline & $\begin{array}{l}\text { Hotelling's } \\
\text { Trace }\end{array}$ & .107 & 2.501 & 16.000 & 1490.000 & .001 & .026 \\
\hline & $\begin{array}{l}\text { Roy's Largest } \\
\text { Root }\end{array}$ & .085 & $7.977 \mathrm{c}$ & 4.000 & 377.000 & $<.001$ & .078 \\
\hline
\end{tabular}

As all the underlying assumptions were supported by the data, a MANOVA was conducted. Findings showed that there was a significant effect on the gender, $\mathrm{F}(4,377)=6.20, p=<.001$, partial $\eta 2=.062$, and level of education, $\mathrm{F}(4,377)=7.97, p=<.001$, partial $\eta 2=.078$ on the combined dependent variable (Table 4). Analysis of the dependent variables individually showed no effects on awareness, knowledge, and attitude towards gender, race, and level of education. However, the practices variable for gender, $\mathrm{F}(1,380)=16.03, p=<.001$, partial $\eta 2=.04$ and level of education, $\mathrm{F}(4,377)=6.174, p=<.001$, partial $\eta 2=.07$ was statistically significant at a Bonferroni adjusted alpha level of .013. As a result, the male secondary school students' $(M=1.05)$ from form $5(M=1.172)$ reported significantly higher in their practices on sexual and healthy reproductive (Table 5).

Table 5: Test Of Between-Subject Effects And Estimated Marginal Means For Gender, And Level Of Education On Each Dependent Variable

\begin{tabular}{|c|c|c|c|c|c|c|c|}
\hline Source & $\begin{array}{c}\text { Dependent } \\
\text { Variable }\end{array}$ & $\begin{array}{c}\text { Type III Sum of } \\
\text { Squares }\end{array}$ & df & $\begin{array}{c}\text { Mean } \\
\text { Square }\end{array}$ & $\mathbf{F}$ & Sig. & $\begin{array}{c}\text { Partial Eta } \\
\text { Squared } \\
\end{array}$ \\
\hline \multirow[t]{4}{*}{ Gender } & Awareness & 20.079 & 1 & 20.079 & 3.245 & .072 & .008 \\
\hline & Knowledge & 5.286 & 1 & 5.286 & 2.267 & .133 & .006 \\
\hline & Attitude & .009 & 1 & .009 & .029 & .864 & $<.001$ \\
\hline & Practice & 14.086 & 1 & 14.086 & 16.035 & .000 & .040 \\
\hline \multirow{4}{*}{$\begin{array}{l}\text { Level of } \\
\text { Education }\end{array}$} & Awareness & Awareness & 37.859 & 4 & 9.465 & 1.529 & .193 \\
\hline & Knowledge & Knowledge & 5.345 & 4 & 1.336 & .569 & .686 \\
\hline & Attitude & Attitude & 1.933 & 4 & .483 & 1.665 & .158 \\
\hline & Practice & Practice & 24.697 & 4 & 6.174 & 7.202 & .000 \\
\hline Source & Descriptive & $\begin{array}{c}\text { Dependent } \\
\text { Variable }\end{array}$ & Mean & S. D & & & \\
\hline \multirow[t]{2}{*}{ Gender } & Male & Practice & 1.051 & .075 & & & \\
\hline & Female & & .661 & .063 & & & \\
\hline \multirow[t]{3}{*}{$\begin{array}{l}\text { Level of } \\
\text { Education }\end{array}$} & Form 1 & Practice & .100 & .207 & & & \\
\hline & Form 2 & & .667 & .169 & & & \\
\hline & Form 3 & & .703 & .097 & & & \\
\hline
\end{tabular}


Form 4

Form 5
.789

.078

1.172
.093

\section{Discussion}

The sexual and reproductive health awareness, level of knowledge, attitude, and practices among secondary school students in Malaysia were examined. Most of the school students exhibit a moderate level of awareness on all aspects of SRH except on the menstrual cycle which is reported to be the highest. This gives the impression whereby female students in Malaysia are aware of women's health which was deemed to be critical as it links to their fertility, gynaecological, hormonal issues, and digestive disorders (Essity, 200). However, as per evidence, many of the students are not aware of the abortion services and related information available in Malaysia, consistent with another study by Awang et al. (2014). To is concerning because abortion is linked to sexual and reproductive health. In Malaysia, abortion is legal if only the fetus poses a threat to the mother's life as per Sections 31-316 of the Penal Code in Malaysia's Federal Constitutions (Law of Malaysia Act 574, 1989). Nevertheless, abortion can be performed in other countries following the World Health Organization (2019b), which protect women's and girls' human right and well-being.

As for the level of knowledge, the only questions that were not correctly answered by the majority of the students were regarding sexually transmitted diseases (STD). This was due to the appearance and presentation of STD's patient which was reported to be normal and healthy despite transmitting the pathogens. It was also confirmed that up to $90 \%$ of STDs do not manifest symptoms unless clinically observed and tested (Wagenlehner, 2006). Kidshealth (2015) agreed that there is no way to tell if a person has an STD by looking at him with their own eyes unless he has been medically tested. According to Santos-Longhurst (2020), some cases of STDs do not exhibit any symptoms at all. Lack of general knowledge of STDs would probably give the impression of incorrect answers in most of the students.

As per the demographics, most of the students in this group represented the Malay ethnic group with Islamic background as their religion. This illustrates the attitude of not permitting sexual intercourse before marriage. Furthermore, a high level of disagreement was also reported with the statement of hugging and kissing deemed to be accepted without any sexual intercourse. Since Malaysia is an Islamic country, the government strongly emphasizes the concept of "La Taqrabuzzina" which preaches people on how to control their lust while they were in a relationship with the opposite gender (Arifin, 2020). In addition, the concept of "Khulwah" which translates to an interaction between a man and a woman without any company from the women's side, is strictly prohibited in Islamic teaching (Hussein, 2017). As a result, most Muslims believe that if a man and a woman being together in a remote location is illegal, then sexual conduct between them must be the highest sin committed by the couple.

Furthermore, most students agreed that a man and woman will lose their confidence and dignity if they engage in sexual intercourse before marriage because sexual intercourse among teenagers can cause emotional disturbance and negative psychological effects. Sexual permissiveness breeds feelings of worthlessness and self-disgust (Meeker, 2014). When teenagers engage in casual sexual intercourse, their intimacy decreases, causing them to feel more stressed (San Francisco Chronicle, 2007; Sina, 2012), which leads to depression and emotional distress (Coleman, 2005; K12 Academics, 2021). The students also disagree with 


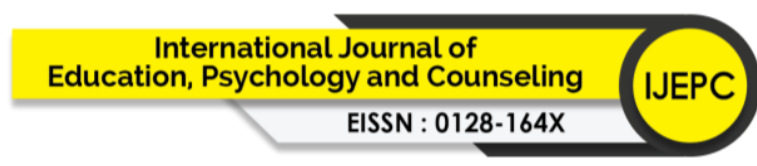

Volume 6 Issue 42 (September 2021) PP. 399-412

DOI 10.35631/IJEPC.642031

abortion being acceptable if a couple had sexual intercourse before marriage. Despite the termination of pregnancies is permitted under Act 574, Penal Code Section 312 as amended in 1989 (Laws of Malaysia Act 574, 1989), if the carrier endangers the mother's life, however, the legalities of abortion in Malaysia are heavily influenced by religious belief (Low et al, 2015). As a result, most Malaysians, including children, will regard abortion as murder of an innocent child, and people's respect for life will suffer as a result (BBC, 2014).

Meanwhile, most students did not engage in harmful behaviours that could jeopardize their sexual and reproductive health. In their lifetime, many of them did not watch or read porn, nor did they engage in sexual intercourse or pregnancies. Pornographic activities are a bad habit that can lead to addiction in humans. According to Pietrangelo (2019), the easy access to pornographic materials online makes it more difficult for people to stop watching them. Based on the relationship between sexual intercourse and pregnancies, unprotected sexual intercourse can result in unwanted pregnancies. Each year, approximately 14 out of every 1000 Malaysian underage girls, or 18,000 of them, become pregnant, according to evidence (Ermisch, 2003; Nagandla and Kumar, 2020; Said, 2019).

Nevertheless, as for practices, this study concludes that male students exhibit better sexual and reproductive health practices as compared to female students. In general, most male students prefer to watch and read pornographic materials. This was also supported by the fact that 60.6 $\%$ of male adolescents in secondary schools watched and read pornographic materials, as compared to $14.9 \%$ of female adolescents (Muhammad Sapri et al, 2012). This was also since most men embrace pornographic as part of their lives and personnel usage (Carroll and Willoughby, 2017). In terms of the level of education, the risk and protective practices among teenagers revealed that a high educational level delays sexual initiation and subsequently makes them more aware of the importance of using contraception and condoms during sexual intercourse. Hence, this also supports the finding in which safe sex practices are well understood by the senior students in this research (Muula, 2011; Mmari, 2013).

In conclusion, a majority of the Malaysian secondary school students are aware of their sexual health and reproductive system. Nevertheless, emphasis was to be made on the area of legal matters including abortion systems. It is also imperative to introduce early teaching of sexual health which includes diseases and prevention as part of the curricula with a more in-depth review to engage students with the current trends of safe sexual practices. Exposing sexual and health practices should also be emphasized especially on female students to increase the awareness equally which will give a positive impact, as well as a preparation before embarking on a relationship with their partners later in life.

\section{Limitation}

One of the limitations can be found in the target group of study. The study is carried out among school students in Petaling Perdana which included students from Form 1 to Form 5. The findings would be varied if they are conducted at different schools because of a different lifestyle, socioeconomic, and other socio-demographic backgrounds.

\section{Conclusion}

Awareness, knowledge, attitude, and practices are the key aspects of determining the student's sexual and reproductive health. This study found that most of the students surveyed show a great level of awareness, an average level of sexual and reproductive knowledge, excellent 


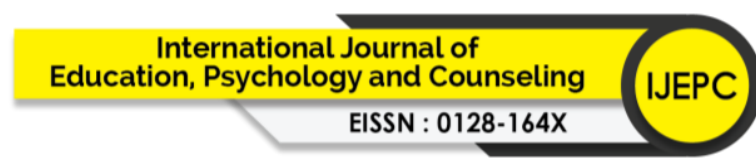

Volume 6 Issue 42 (September 2021) PP. 399-412

DOI 10.35631/IJEPC.642031

attitude and practices while maintaining their sexual and reproductive health. There is also a significant difference between gender and level of education towards practices on sexual and reproductive health, as males reported better sexual practices than females and a person with a higher level of education has better understanding and practices towards their sexual and reproductive health. In a nutshell, it has been eye-opener research as the outcome of the study will give a positive impact on the community.

\section{Acknowledgements}

Special thanks to the school principals and students for their agreement, involvement, support, and effort in the completion of this study. The authors would like to thank the respective experts Mawarni Mohamed (MM), Syarifah Muzlia (SM) \& Mohd Hafriz (MH) for content validation and ratings.

\section{References}

Arifin, L. (2020). Pendidikan seksualiti, cegah seks luar nikah. Berita Harian. https://www.bharian.com.my/wanita/keluarga/2020/10/744763/pendidikan-seksualiticegah-seks-luar-nikah [31 July 2021].

Awang, H., Wong, L.P., Jani, R. \& Low, W.Y. (2014). Knowledge of sexually transmitted diseases and sexual behaviours among Malaysian male youths. Journal of Biosocial Science, 46(2), 214-24.

Carroll, J.S. \& Willoughby, B.J. (2017). The porn gap: Gender differences in pornography use in couple relationships. Institute for Family Studies Charlottesville, VA. https://ifstudies.org/blog/the-porn-gap-gender-differences-in-pornography-use-incouple-relationships [31 July 2021].

Coleman, P. (2005). The complete idiot's guide to intimacy. DK Publishing. https://www.overdrive.com/media/1711665/the-complete-idiots-guide-to-intimacy [31 July 2021].

Ermisch, J. (2003). Does a 'teen-birth' have longer-term impacts on the mother? suggestive evidence from the British household panel study. Colchester: University of Essex. https://www.researchgate.net/publication/5017799_Does_a_Teen-

Birth_Have_Longer-

Term_Impact_on_the_Mother_Suggestive_Evidence_from_the_British_Household_P anel_Study [31 July 2021].

Eshak, Z. \& Zain, A. (2019). The readiness of preschool teachers in terms of the implementation of the Peers Day@ Preschool Program. International Journal of Academic Research in Business and Social Sciences, 9(7), 7.

Essity. (2018). Raising awareness of the menstrual cycle's role for women's health. http://reports.essity.com/2018-19/hygiene-and-health-report/en/women-on-the-

rise/raising-awareness-of-the-menstrual-cycles-role-for-womens-health.html [31 July 2021].

Haberland, N. \& Rogow, D. (2015). Sexuality education: Emerging trends in evidence and practice. Journal of Adolescent Health, 42(1), 15-21.

Hassan, D. (2016). Risk and protective factors affecting adolescents' sexual and reproductive health in Sabah and Sarawak. http://familyrepository.lppkn.gov.my/646/ [31 July 2021].

Hassan, H. \& Muhammad Sapri N.A. (2013). Risk and protective factors affecting adolescents' youth sexual and reproductive health in Peninsular Malaysia. http://familyrepository.lppkn.gov.my/375/ [31 July 2021]. 


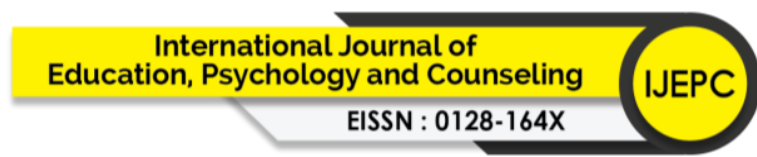

Volume 6 Issue 42 (September 2021) PP. 399-412

DOI 10.35631/IJEPC.642031

Hussein, A.T. (2017). Ikhtilat (percampuran) antara lelaki dan perempuan. Dakwahdantarbiah.com Blog. https://dakwahdantarbiah.com/ikhtilat-percampuranantara-dua-lelaki-dan-perempuan/ [31 July 2021].

Institute for Public Health. (2017a). National health and morbidity survey: Adolescent health survey.

https://iku.gov.my/images/IKU/Document/REPORT/NHMS2017/AHSReportNHMS2 017.pdf [31 July 2021].

Institute for Public Health. (2017b). National Health and Morbidity Survey (NHMS). http://iku.moh.gov.my/images/IKU/Document/REPORT/NHMS2017/ANS_KUALA LUMPUR.pdf. [31 July 2021].

Ismail, R.N. \& Minhat, H.S. (2019). Sociodemographic determinants of good sexual and reproductive health (SRH) knowledge among secondary school children in Kuantan, Pahang, Malaysia. Malaysian Journal of Medicine and Health Sciences, 15(2), 104-11.

K12academics. (2021). Psychological effects. https://www.k12academics.com/sexeducation/adolescent-sexuality-united-states/psychologicaleffects\#:\%7E:text=Doctor\%20of\%20adolescent\%20medicine\%20Meg,course $\% 2 \mathrm{C} \% 2$ Oprecursors\%20to\%20depression.\%E2\%80\%9D [31 July 2021].

Kidshealth. (2015). How can I find out if my boyfriend has an STD before we have sex? https://kidshealth.org/en/teens/std-talk.html [31 July 2021].

Krejcie, R.V. \& Morgan, D.W. (1970). Determining sample size for research activities. Educational and Psychological Measurement, 30(3), 607-10.

$\begin{array}{llllll}\text { Laws } & \text { of } & \text { Malaysia } & \text { Act } & 574 & 1989,\end{array}$ https://www.ilo.org/dyn/natlex/docs/ELECTRONIC/61339/117909/F-

833274986/MYS61339\%202018.pdf [31 July 2021].

Lembaga Penduduk dan Pembangunan Keluarga Negara (LPPKN). (2017). Dasar dan pelan tindakan pendidikan kesihatan reproduktif dan sosial kebangsaan. https://www.lppkn.gov.my/index.php/perkhidmatan-kesihatan-reproduktif/199-dasardan-pelan-tindakan-pendidikan-kesihatan-reproduktif-dan-sosial-kebangsaan-2 [31 July 2021].

Low, W.Y., Tong, W.T., Wong, Y.L., Jegasothy, R. \& Choong, S.P. (2015). Access to safe legal abortion in Malaysia: Women's insights and health sector response. Asia Pacific Journal of Public Health, 27(1), 33-7.

Meeker, M. (2014). Depression - The Emotional STD. Meeker Parenting Blog. https://www.meekerparenting.com/blog/depression-the-emotional-std [31 July 2021].

Ministry of Education Malaysia. (2020). Maklumat asas pendidikan negeri Selangor: mod pengurusan sekolah

(EMiS). https://app.powerbi.com/view?r=eyJrIjoiYWRhNGIxY2QtYzU2NS00MTk1LWI2M GEtMGYyMmU2NjE5MzgxIiwidCI6ImQ3M2UwNDFkLWE2MzAtNDg5NS05Nm ZlLWRiMGUxZTc0Y2Y5OCIsImMiOjEwfQ\%3D\%3D [31 July 2021].

Mmari, K. Sabherwal, S. (2013). A review of risk and protective factors for adolescent sexual and reproductive health in developing countries: An update. Journal of Adolescent Health, 53(5), 562-72.

Mokhtar, M.M. Rosenthal, D.A. Hocking, J.S. \& Satar, N. A. (2013). Bridging the gap: Malaysian youths and the pedagogy of school-based sexual health education. ProcediaSocial and Behavioral Sciences, 85, 236-245.

Muhammad Sapri N.A., Ahmad, N., Ishak, I., Ahmad, N.A \& Aris, T. (2012). Kajian kesihatan reproduktif \& seksual remaja. http://familyrepository.lppkn.gov.my/244/ [31 July 2021]. 


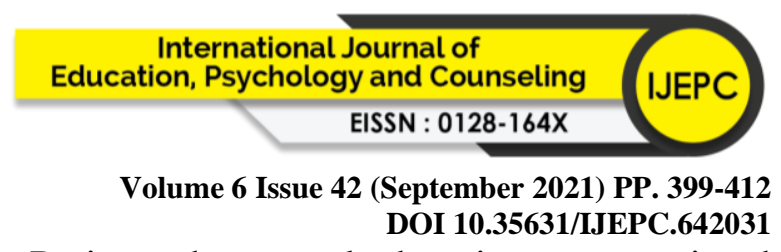

Muula, A.S., Siziya, S. \& Rudatsikira, E. (2011). Parity and maternal education are associated with low birth weight in Malawi. African Health Sciences, 11(1).

Nagandla, K. \& Kumar, K. (2020). Prevalence of teenage pregnancy in 2015-2016 and its obstetric outcomes compared to non-teenage pregnancy at Hospital Tuanku Ja'afar Seremban (HTJS), Negeri Sembilan, Malaysia: A retrospective case-control study based on the national obstetric registry. Malaysian Family Physician: The Official Journal of The Academy of Family Physicians of Malaysia, 15(2), 2.

Othman, S., Kong, S.Z., Mydin, F.M. \& Ng, C.J. (2019). Knowledge, utilization and barriers to primary care services for sexual and reproductive health among adolescents in secondary schools in Selangor, Malaysia. Malaysian Family Physician: The Official Journal of The Academy of Family Physicians of Malaysia, 14(1), 10.

Pietrangelo, A. (2019). Everything you need to know about pornography 'addiction'. https://www.healthline.com/health/pornography-addiction [31 July 2021].

Razali. S., Ramli, N.A., Hanafia, S.S. Abdul Rahman N.N, Md K.N. Rani, M.A. Hassan, M.A. Ariffin, A.F. (2017). Are Malaysians ready for comprehensive sexuality education. Journal of Advanced Research in Social and Behavioural Sciences, 9(1), 14-28.

Said, S. (2019). Teenage pregnancy: Who is to blame? Bernama Health. http://health.bernama.com/news.php?id=1679119 [31 July 2021].

San Francisco Chronicle. (2007). Post-sex emotions differ for boys, girls. PressReader. https://www.pressreader.com/usa/san-franciscochronicle/20070215/281943128416580 [31 July 2021].

Santos-Longhurst, A. (2020). Signs and symptoms of common STDs in men. https://www.healthline.com/health/mens-health-signs-of-common-stds [31 July 2021].

Shukor, S.A. \& Supaat, D.I. (2018). Legal appraisal of sex education in Malaysian schools. International Journal, 8, 21-31.

Sina. (2012). Adolescent sexuality in the United States 美国青少年性行为_频载酒_新浪博 客. In: SINA BLOG. http://blog.sina.cn/dpool/blog/s/blog_58acfbf601015o9p.html [31 July 2021].

The British Broadcasting Corporation (BBC). (2014). Introduction to the abortion debate. http://www.bbc.co.uk/ethics/abortion/philosophical/introduction.shtml\#h1 [31 July 2021].

UNESCO. International technical guidance on sexuality education. France: UNESCO Open Access Repository Online. http://unesdoc.unesco.org/images/0026/002607/260770e.pdf [31 July 2021].

Wagenlehner, F.M., Brockmeyer, N.H., Discher, T. Friese, K. \& Wichelhaus, T.A. (2016). The presentation, diagnosis, and treatment of sexually transmitted infections. Deutsches Ärzteblatt International, 113(1-2), 11.

World Health Organization. (2019a). Sexual health. https://www.who.int/health-topics/sexualhealth\#tab=tab_1 [31 July 2021].

World Health Organization. (2019b). Abortion. https://www.who.int/healthtopics/abortion\#tab=tab_1 [31 July 2021]. 